\title{
Diagnostics based on the juxta morphology reveals a new species of Tischeria Zeller (Lepidoptera, Tischeriidae) from the Caucasus
}

\author{
Adam Klasiński ${ }^{1}$ \\ Jonas Rimantas Stonis ${ }^{2}$, \\ Andrius Remeikis ${ }^{2}$ \\ ${ }^{1}$ Częstochowskie Koło Entomologiczne \\ przy Muzeum Częstochowskim, \\ Aleja NMP 47, 42-217, Częstochowa, Poland \\ ${ }^{2}$ Institute of Ecology, \\ Nature Research Centre and \\ Baltic-American Biotaxonomy Institute, \\ Akademijos St. 2, Vilnius 08412, Lithuania
}

\begin{abstract}
We describe a new species, Tischeria caucasica Klasiński \& Stonis, sp. nov., a trumpet moth (Tischeridae) recently discovered from Georgia, the Caucasus. We briefly discuss the diagnostics of T. caucasica, an outstanding new species possessing an extremely long and distally bifurcated juxta. The new species is illustrated with photographs of the adults, male and female genitalia, and the type locality.
\end{abstract}

Keywords: leaf miners, new species, Tischeria caucasica, trumpet moths

\section{INTRODUCTION}

Tischeriidae, or trumpet moths, represent a small but important family of leaf-mining Lepidoptera. Trumpet moths are almost cosmopolitan: various species are known from all continents except Australia and Antarctica. They are represented in very diverse terrestrial ecosystems, from the tropics to the temperate regions; however, the family is more abundant in subtropical and tropical areas (Stonis et al., 2018). For morphological and biological characterization of Tischerridae, we recommend the monographs by Braun 1972 and

* Corresponding author. Email: stonis.biotaxonomy@gmail.com
Puplesis, Diškus 2003 and the most recent papers by Lees, Stonis, 2007; Stonis, Diškus, 2007, 2008; Stonis et al., 2008, 2016, 2017, 2018, 2019; Mey, 2010; Diškus et al., 2014; Diškus, Stonis, 2015; and Xu et al., 2017, 2018.

In May 2019, the first author, Adam Klasiński, conducted a fieldwork in central Georgia (Figs. 1-5), Kartli, near Kura River (Fig. 4). The landscape was rather denuded, semiarid, steppe-like (Figs. 2, 5), currently used mostly as pastures, where bushes or young trees were scanty and occurring mostly in ravines (Fig. 3). During the fieldwork, a series of tischeriids were collected among many other moths. Externally, the collected specimens resembled Tischeria ekebladella 

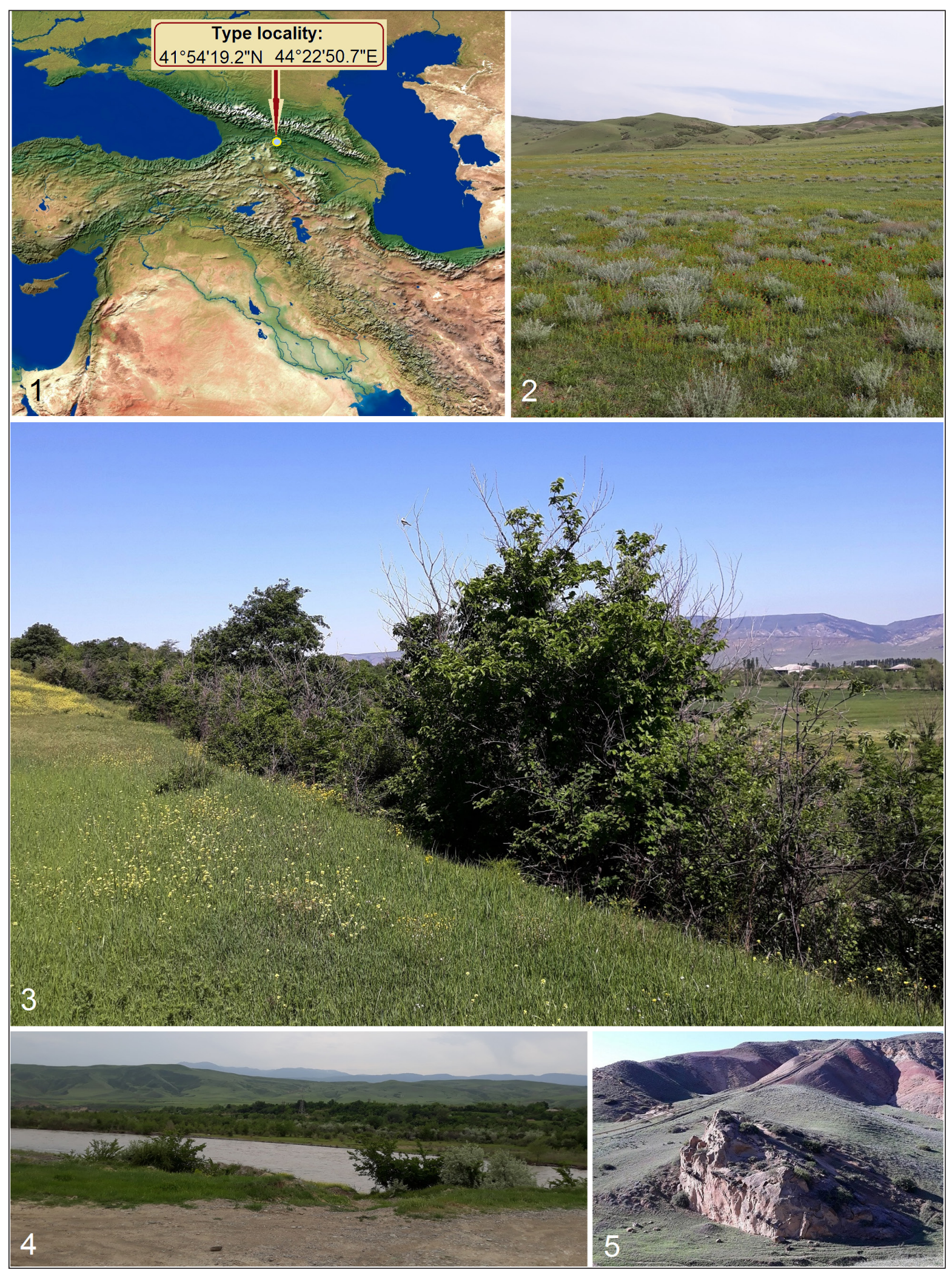

Figs. 1-5. Type locality and habitat of Tischeria caucasica Klasiński \& Stonis, sp. nov. 1, 2, 4, 5 - type locality, Georgia, Kartli, Gomi, 41 $54^{\prime} 19.2^{\prime \prime N}, 44^{\circ} 22^{\prime} 50.7^{\prime \prime} \mathrm{E} ; 3$ - habitat, a stand of bushes and young trees occurring in a ravine, elevation $570-710 \mathrm{~m}$ 
(Bjerkander, 1795), a species widely distributed in Europe and reported from the Caucasus (Diškus, Puplesis, 2003). However, our detail examination of the male genitalia showed that the juxta strongly differed from those of Tischeria ekebladella or another similar species, T. ekebladoides Puplesis \& Diškus, 2003 (Fig. 6).

Below we name and describe this new species, Tischeria caucasica sp. nov., characterized mostly by a unique juxta in the male genitalia as well as some unique but not so conspicuous characters of the female genitalia. We provide a detail documentation of genital structures of the male genitalia as well as photographs of the adults and the female genitalia.

\section{MATERIALS AND METHODS}

The description of the new species is based on the material collected by Adam Klasiński in Georgia in 2019. The majority of the type material, including the holotype and single available female, will be deposited in the collection of the Zoological Institute of the Russian Academy of Sciences, St. Petersburg, Russia (ZIN).
In addition, two male paratypes of Tischeria caucasica will be deposited in the collection of the Muzeum Częstochowskie, Częstochowa, Poland (MUZC) and other two in the private collection of Adam Klasiński, Częstochowa, ul. Łukasińskiego 88/8, Poland (PCAK).

Collecting methods and protocols for species identification and description are outlined in Puplesis, Diškus (2003) and Stonis et al. (2014). Permanent preparations on microscope slides were photographed and studied with a Leica DM2500 microscope and Leica DFC420 digital camera. Adults were photographed using a Leica S6D stereoscopic microscope with a Leica DFC290 digital camera attached.

\section{DESCRIPTION OF TISCHERIA CAUCA- SICA KLASIŃKI \& STONIS, SP. NOV.}

Type material. Holotype: $\overbrace{}^{\lambda}$, GEORGIA, Kartli, Gomi, 41 ${ }^{\circ} 54^{\prime} 19.2^{\prime \prime} \mathrm{N}, 44^{\circ} 22^{\prime} 50.7^{\prime \prime}$ E, elevation 570-710 m, at light, 5-21.v.2019, leg. Adam Klasiński, genitalia slide no. RA1080 (ZIN). Paratypes: $2 \AA, 1$ ㅇ, same label data as holo-

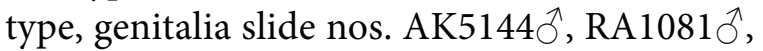
RA1082 + (ZIN); 2 , same label data as

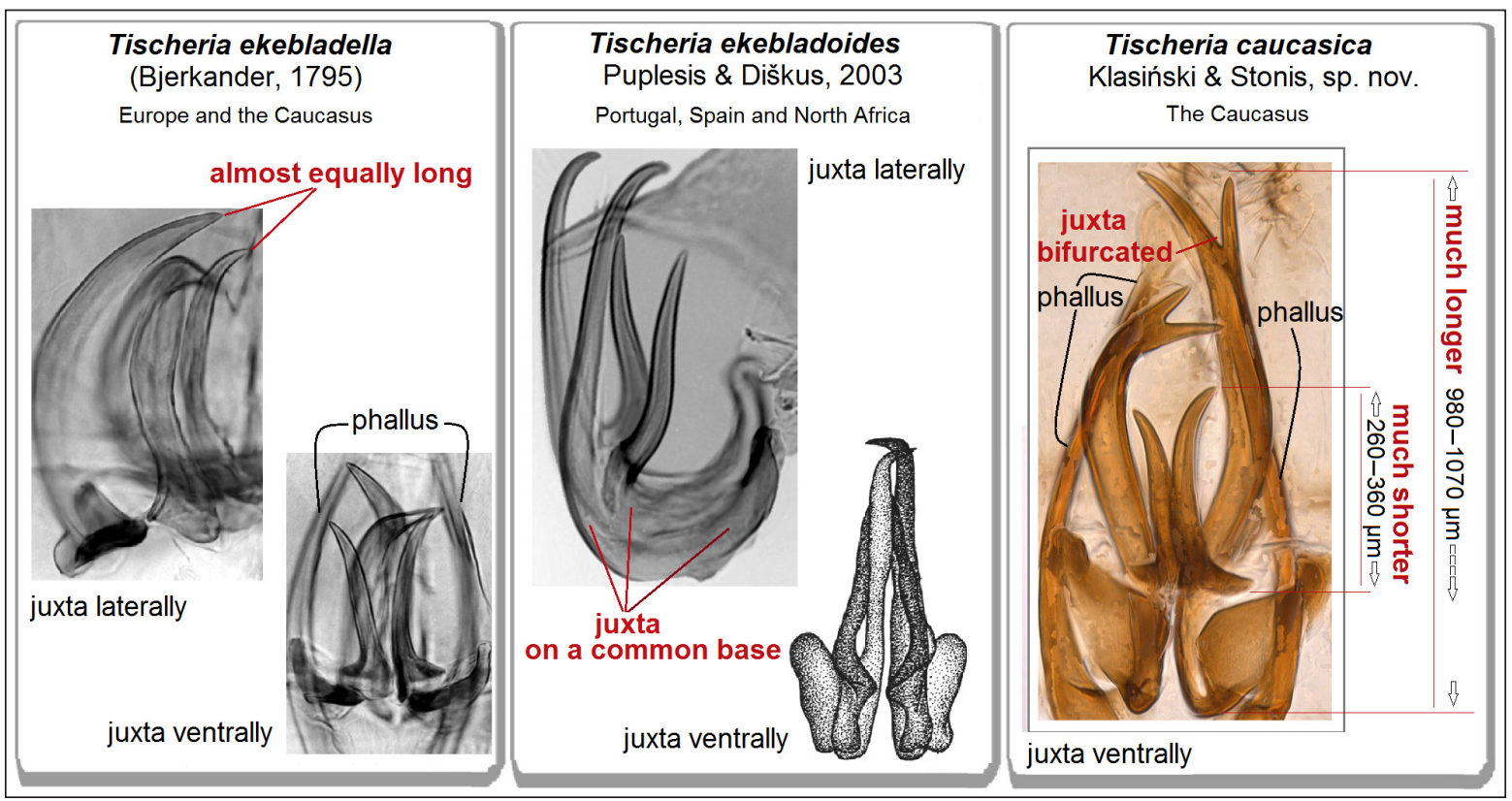

Fig. 6. Diagnostics of Tischeria caucasica Klasiński \& Stonis, sp. nov. based on the juxta in the male genitalia (a comparison with the most resembling species, T. ekebladella and T. ekebladoides) 
holotype, genitalia slide no. AK5143 (PCAK); $2 \hat{\jmath}$, same label data as holotype (MUZC).

Diagnosis. Externally, Tischeria caucasica sp. nov. can be confused with many other uniform Tischeria species, including T. ekebladella (Bjerkander, 1795) and T. ekebladoides Puplesis \& Diškus. In the male genitalia, the unique, very long and distally bifurcated juxta distinguishes the new species from all known congeneric species, including the most similar T. ekebladella and T. ekebladoides (Fig. 6). In the female genitalia, this species also differs from all congeneric species, including the most resembling T. ekebladella, T. sichotensis Ermolaev, 1986, and T. ekebladoides by the combination of a weakly chitinized anterior margin of antrum (Fig. 32) with unique membranous part (Fig. 35), and a wide base of the shortest prela (Fig. 33); however, these characters, in comparison to the male genitalia, are far less conspicuous and less useful for species differentiation.

Male (Figs. 7-12). Forewing length 4.2$4.8 \mathrm{~mm}$; wingspan 9.1-10.1 mm $(n=3)$. Head: palpi cream; frons golden cream, very glossy; frontal tuft (Figs. 8-10) overlapping the frons, comprised of long, lamellar, yellowish ochre or ochre cream scales; collar (Fig. 8) ochre cream to yellowish ochre, comprised of lamellar scales; antenna much longer than one half the length of forewing; flagellum ochre cream on upper side, dark brown on underside. Thorax ochre cream; tegula ochre cream to yellowish ochre, proximally densely covered with grey scales. Forewing (Figs. 11, 12) densely covered with yellowish ochre to ochre cream scales, apically with some darker, ochre scales; fringe yellowish ochre; fringe line absent; underside of forewing densely covered with dark grey scales. Hindwing dark grey on upper side and underside, however, may look greyish cream depending from the angle of view; fringe grey to ochre cream depending from the angle of view. Legs ochre cream, covered with pale grey scales laterally; forelegs with blackish to grey scales on upper side. Abdomen glossy, with inconspicuous purple iridescence, pale yellowish brown basally, dark grey distally; underside of abdomen predominantly dark yellow-brown; genital plates ochreous cream; anal tufts indistinctive (or partially rubbed), ochreous cream.

Female (Figs. 13, 14). Forewing length about $4.5 \mathrm{~mm}$; wingspan about $9.5 \mathrm{~mm}(n=1)$. Abdomen without anal tufts; otherwise, similar to male.

Male genitalia (Figs. 15-31). Capsule significantly longer $(1395-1570 \mu \mathrm{m})$ than wide $(755-780 \mu \mathrm{m})$. Uncus (Fig. 16) with two large lateral lobes. Socii membranous (Fig. 17). Valva (Figs. 18, 29, 30) 940-1035 $\mu \mathrm{m}$ long, narrowing distally; transtilla absent. Juxta (Figs. 15, 18, 21-25, 27, 28, 31) comprised of two shorter $(260-360 \mu \mathrm{m})$ and two very long (980-1070 $\mu \mathrm{m}$ ) horn-like processes (Fig. 6); the latter bifurcated distally and bent basally (see Figs. 21-25). Vinculum with a triangularly-shaped, slender ventral plate (Figs. 15, 16). Phallus (Figs. 19, 20, 26) 1190-1215 $\mu \mathrm{m}$ long, basally $80-150 \mu \mathrm{m}$ wide, but broadly bifurcated in apical half (Fig. 20), with weakly chitinized plates on the top of each branch (Fig. 19).

Female genitalia (Figs. 32-35). Total length about $2700 \mu \mathrm{m}$. Antrum elaborated (Fig. 32) but little chitinized anteriorly. The shortest process of prela with a wide, plate-like base (Fig. 33). Ductus bursae with spines. Corpus bursae heavily folded but without signum or pectinations (Fig. 34). Ductus spermathecae with about 4-5 large coils.

Bionomics (Figs. 2-5). Host plant is unknown, probably Quercus sp. as the closely related Tischeria ekebladella is an oak-feeding species (also see Discussion). Larva and leaf mine are unknown; however, as in the case of all other Tischeria species, T. caucasica is supposed to be a leaf-mining insect. Adults were collected at light in May. Otherwise, biology is unknown.

Distribution. Currently known from a single locality in Georgia (the Caucasus), at an elevation of about 570-710 m (Fig. 1).

Etymology. This species is named after the Caucasus where it occurs. 

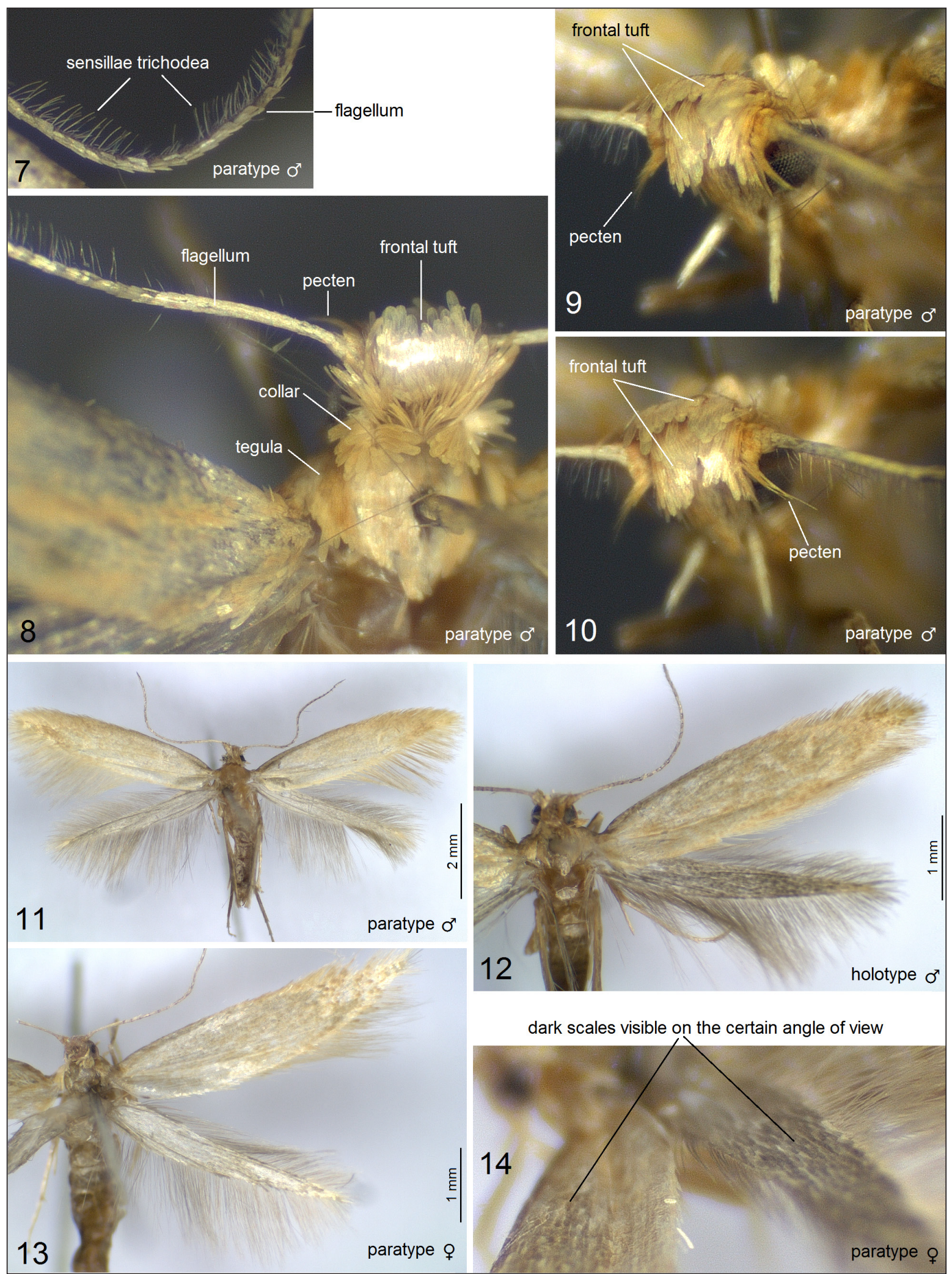

Figs. 7-14. Adult of Tischeria caucasica Klasiński \& Stonis, sp. nov. 7 - male antenna with sensillae trichodea; 8 - frontal tuft, dorsal view; 9, 10 - same, frontal view; 11 - general view of adult, male paratype (ZIN); 12 - right side of the adult, male holotype (ZIN); 13 - same, female paratype (ZIN); 14 - same, details of scaling at different angle of view 


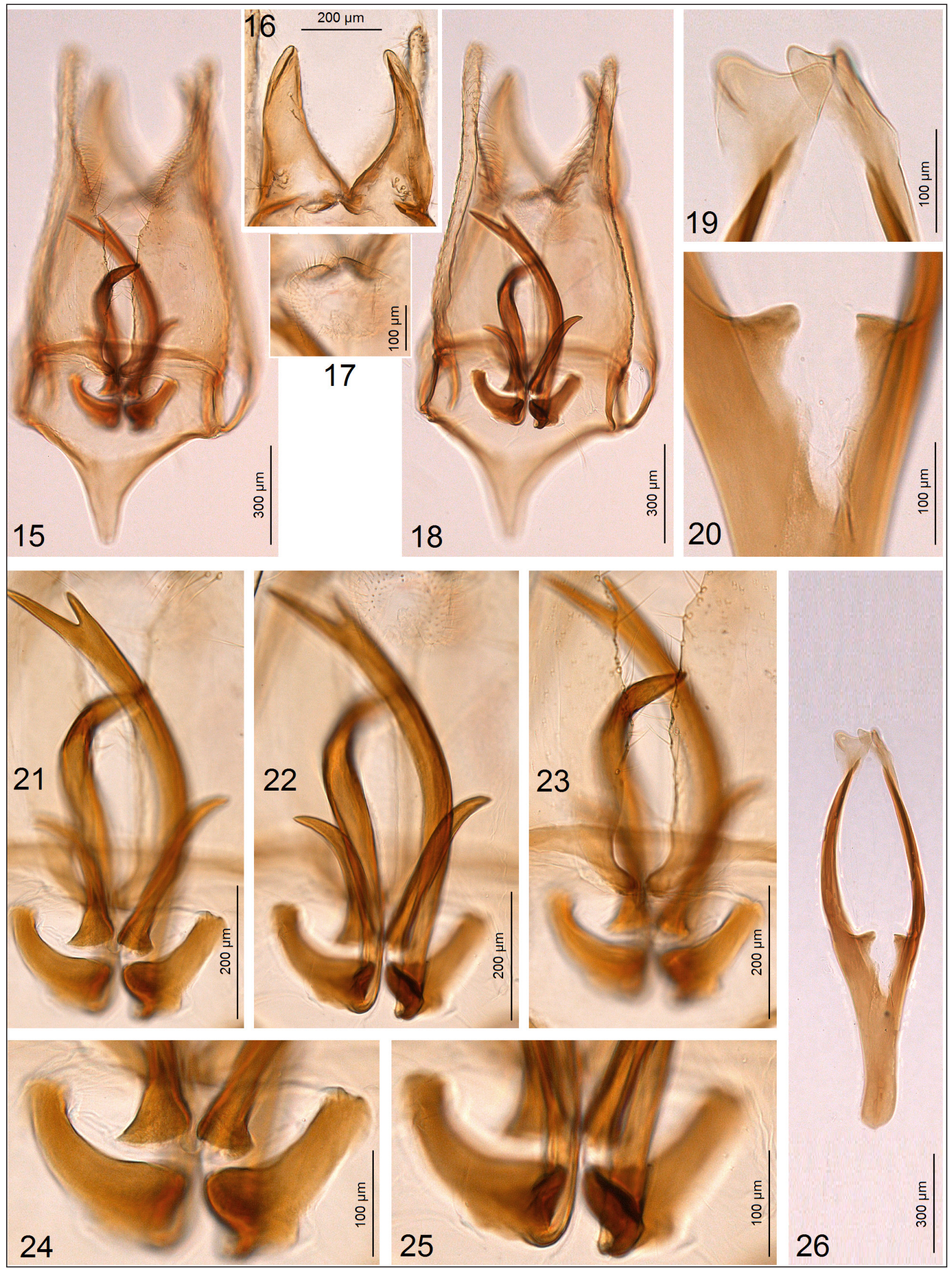

Figs. 15-26. Documentation of the male genitalia of Tischeria caucasica Klasiński \& Stonis, sp. nov., holotype, genitalia slide no. RA1080 (ZIN). 15, 18 - general view, with phallus removed; 16 - uncus; 17 - socii; 19, 20 - details of phallus; 21-25 - details of juxta; 26 - phallus, general view 


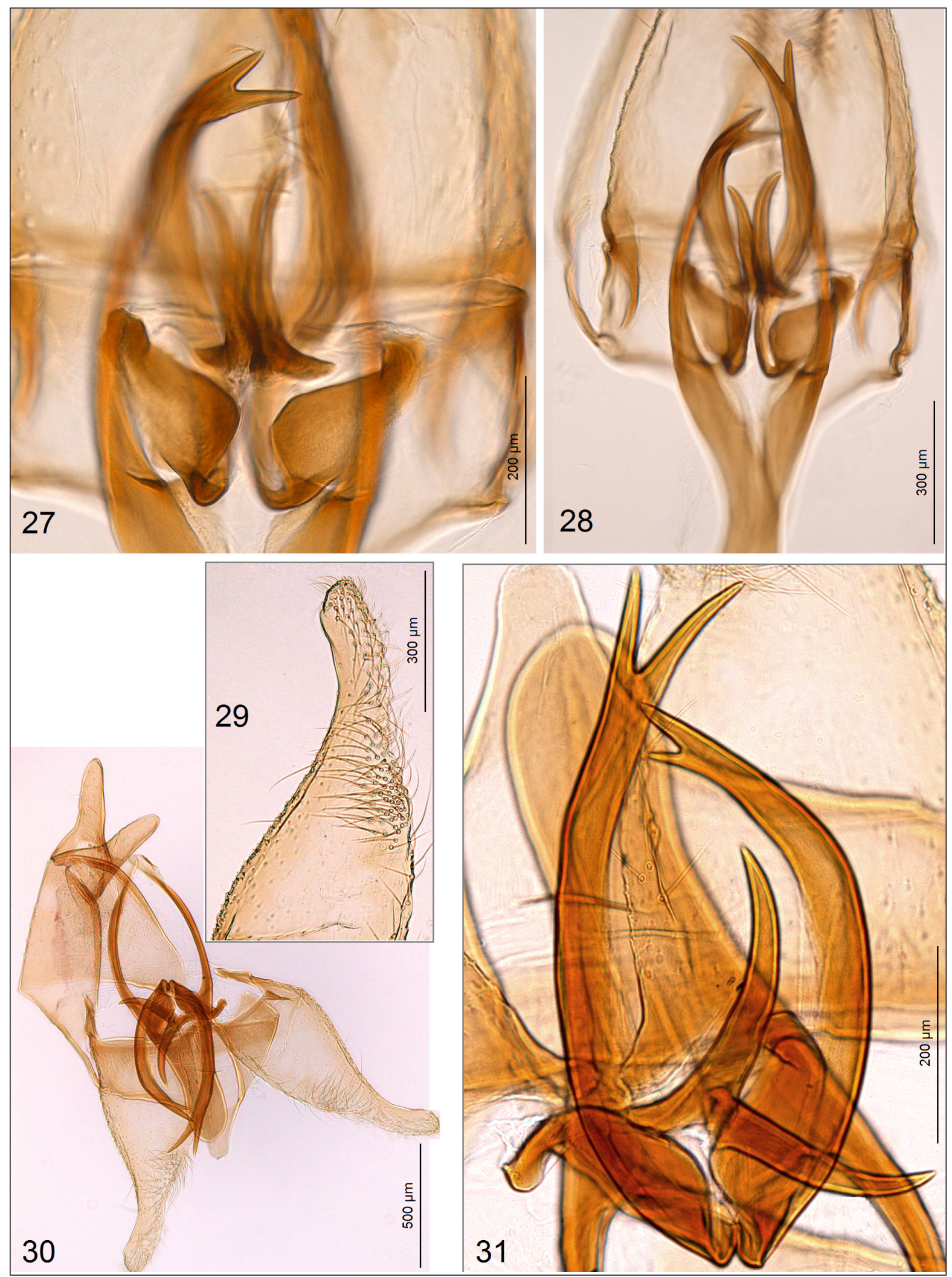

Figs. 27-31. Documentation of the male genitalia of Tischeria caucasica Klasiński \& Stonis, sp. nov. 27, 28 - fragment of capsule with phallus inside, paratype, genitalia slide no. RA1081 (ZIN); 29, 30 - capsule with phallus inside, paratype, genitalia slide no. AK5144 (ZIN); 31 - same, juxta 


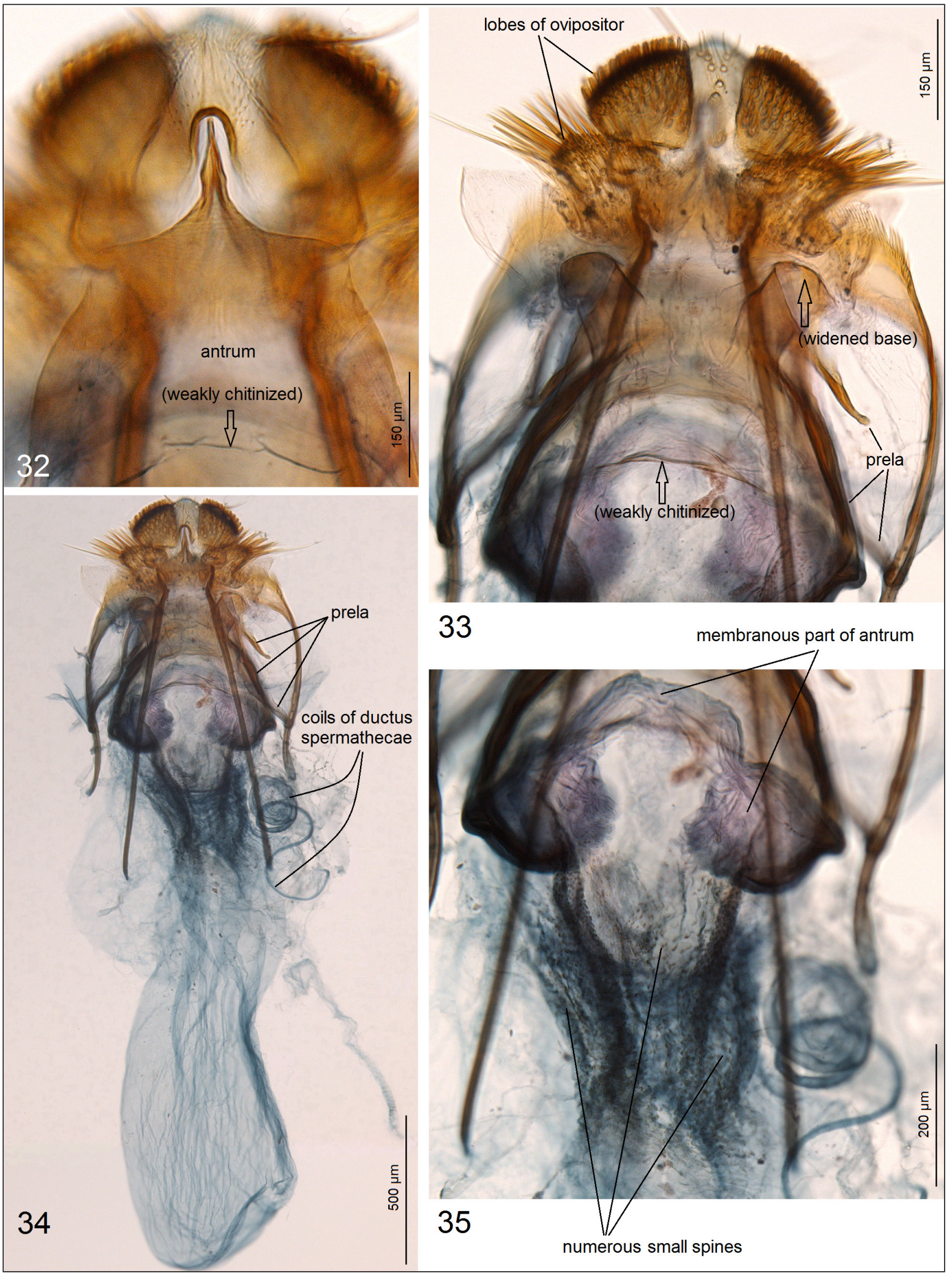

Figs. 32-35. Documentation of the female genitalia of Tischeria caucasica Klasiński \& Stonis, sp. nov., paratype, genitalia slide no. RA1082 (ZIN). 32 - antrum, without a membranous part; 33 - prela and ovipositor; 34 - general view; 35 - membranous part of antrum and spines on ductus bursae 


\section{DISCUSSION}

As regards the male genitalia, Tischeria caucasica sp. nov. appears to be an outstanding taxon: a species possessing a very unusual, long and distally bifurcated juxta. In general, the male genitalic characters of Tischeriidae are wellknown for their great taxonomic and systematic value since in Tischeria, the adult scaling or wing venation is only rarely useful because its uniformity. The male genitalia of tischeriids exhibit some diversity and modification across genera and some structures (characters) appear particularly informative and important for species delimitation: a shape of the dorsal processes of the valva and phallus in Astrotischeria Puplesis \& Diškus, various modifications of the anellus in Paratischeria Diškus \& Stonis, or spines on the "tulip"-shaped phallus in Coptotriche Walsingham. In the genus Tischeria Zeller, a male genitalic structure widely known as the "juxta" is present in all species (but absent in all other Tischeriidae genera) and, therefore, various modifications of this character are especially useful for species diagnostics and probably for some phylogenetical treatments. It is widely known that the organs of the genitalia of insects are under strong reproductive and evolutionary pressures and, therefore, they hold a wide range of informative morphological characters for taxa at different levels (Nakahara et al., 2019). The long and distally bifurcated juxta of Tischeria caucasica sp. nov. (Fig. 6) appears to be highly derived in comparison with the related species, including the most similar T. ekebladella and T. ekebladoides.

The host plant of Tischeria caucasica sp. nov. was not detected during our study and, therefore, remains unknown. However, it should be noted that all other morphologically similar tischeriids from Europe or East Asia and North America are oak-feeding and associated with various species of Quercus L. In the locality where T. caucasica sp. nov. was collected (Fig. 3), the following Quercus species occur: Q. petraea (Matt.) Liebl., Q. macranthera Fisch. \& C. A. Mey. ex Hohen., and $Q$. robur $\mathrm{L}$. The larvae of the new species may feed at least on one of them.

\section{CONTRIBUTIONS TO THE RESEARCH}

Contributions to this research are as follows: Adam Klasiński - fieldwork and collecting of all adult specimens of the type series, photographic documentation of the type locality and habitat, proving information and photographs (Figs. 2-5), preparation of genitalia slides of two male paratypes; Jonas Rimantas Stonis the concept and design of the research, diagnostics and identification of the new species, writing the manuscript, and technical preparation of all tables of illustrations; Andrius Remeikis - dissection, photographic documentation, and measuring of $T$. caucasica sp. nov., providing scales on all tables of illustrations, some additional labelling of the material collected by Adam Klasiński, discussion on diagnostics of Tischeria, compiling the list of references.

\section{ACKNOWLEDGEMENTS}

The first author thanks Jarosław Klasiński, the chairman of the Częstochowskie Koło Entomologiczne (Częstochowa, Poland), for the fruitful and enjoyable collaboration and great companionship during the fieldwork in Georgia in 2019.

This research was partially funded by a grant (S-MIP-19-30, "DiagnoStics") from the Research Council of Lithuania. Andrius Remeikis is grateful to the Research Council of Lithuanian for the research stipend he was awarded in 2019.

Received 9 January 2020

Accepted 18 January 2020

\section{References}

1. Bjerkander C. Phalaena Ekebladella en ny Nattfáril belkrifven. Kungliga Svenska Vetenskapsakademiens Handlingar. 1795; 16: 58-63. Swedish.

2. Braun AF. Tischeriidae of America North of Mexico (Microlepidoptera). Memoirs of the 
American Entomological Society. 1972; 28: 1-148.

3. Diškus A, Puplesis R. Catalogue of the world Nepticuloidea \& Tischerioidea. In: Puplesis R, Diškus A, editors. The Nepticuloidea \& Tischerioidea (Lepidoptera) - a global review, with strategic regional revisions. Kaunas: Lutute Publishers; 2003; p. 318-436.

4. Diškus A, Stonis JR. Astrotischeria neotropicana sp. nov. - a leaf-miner on Sida, Malvaceae, currently with the broadest distribution range in the Neotropics (Lepidoptera, Tischeriidae). Zootaxa. 2015; 4039(3): 456-66.

5. Diškus A, Stonis JR, Cumbicus Torres N. First discovery of leaf-mining Nepticulidae and Tischeriidae (Lepidoptera) associated with the Chilean endemic genus Podanthus Lag. (Asteraceae) as a host-plant. In: Stonis JR, Hill SR, Diškus A, Auškalnis T, editors. Selected abstracts and papers of the First Baltic International Conference on Field Entomology and Faunistics. Vilnius: Edukologija Publishers; 2014; p. 30-1.

6. Ermolaev VP. Novye vidy odnocvetnykh molej - minerov (Lepidoptera, Tischeriidae) $s$ Dal'nego Vostoka [New species of monochromatic miner moths (Lepidoptera, Tischeriidae) from the Far East] (in Russian). In: Ler PA editor. Sistematika i ekologija Cheshuekrylykh Dal'nego Vostoka SSSR [Systematics and ecology of Lepidoptera from the Far East of the USSR]. 1986; 6-8. Vladivostok.

7. Lees DC, Stonis JR. The first record of Tischeriidae (Insecta: Lepidoptera) from Madagascar, with description of Coptotriche alavelona sp. n. and an update distributional checklist of Afrotropical Tischeriidae. Zootaxa. 2007; 1645: 35-45.

8. Mey W. Two new species of Tischeriidae from East Africa (Lepidoptera, Tischerioidea). Esperiana Memoir. 2010; 5: 337-40.

9. Nakahara S, Matos-Maraví P, Barbosa EP, Willmott KR, Lamas G, Freitas AVL. Two new species of Taygetina with a possible case of 'juxta loss' in butterflies (Lepidoptera:
Nymphalidae: Satyrinae). Insect Systematics and Diversity. 2019; 3(6): 1-13. doi: 10.1093/ isd/ixz023

10. Puplesis R, Diškus A. The Nepticuloidea \& Tischerioidea (Lepidoptera) - a global review, with strategic regional revisions. Kaunas: Lututè Publishers; 2003. 512 p.

11. Stonis JR, Diškus A. Distribution of Tischeria gouaniae sp. n. from the tropical forest of Belize - an exotic new addition to the American fauna of Tischeria (Insecta: Lepidoptera: Tischeriidae). Zoological Science. 2007; 24(12): 1286-91. https://doi.org/10.2108/zsj.24.1286

12. Stonis JR, Diškus A. Checklist of American Coptotriche (Insecta: Lepidoptera: Tischeriidae) with descriptions of two new species from the tropical forest of Belize (Central America). Zoological Science. 2008; 25(1): 99-106. https://doi.org/10.2108/zsj.25.99

13. Stonis JR, Diškus A, Carvalho Filho F, Lewis OT. American Asteraceae feeding Astrotischeria species with a highly modified, threelobed valva in the male genitalia (Lepidoptera, Tischeriidae). Zootaxa. 2018; 4469(1): 1-69. doi.org/10.11646/zootaxa.4469.1.1

14. Stonis JR, Diškus A, Paulavičiūtè B, Monro AK. Urticaceae-feeders from the family Tischeriidae: descriptions of two new species and new genus Paratischeria gen. nov. Biologija. 2017; 63(1): 1-22.

15. Stonis JR, Diškus A, Remeikis A, Cumbicus Torres N. First description of leaf-mining Nepticulidae and Tischeriidae (Insecta, Lepidoptera) feeding on the Chilean endemic plant genus Podanthus Lag. (Asteraceae). Zootaxa. 2016; 4061(2): 119-30. http://dx.doi. org/10.11646/zootaxa.4061.2.2

16. Stonis JR, Diškus A, Remeikis A, Navickaitè A. Study methods of Nepticulidae: micromounts of genitalia structures. In: Stonis JR, Hill SR, Diškus A, Auškalnis T, editors. Selected abstracts and papers of the First Baltic International Conference on Field Entomology and Faunistics. Vilnius: Edukologija Publishers; 2014. p. 32-5. 
17. Stonis JR, Diškus A, Sruoga V. Redescription of Coptotriche pulverea (Walsingham) - an unusual species of the American Tischeriidae fauna (Insecta: Lepidoptera). Acta Zoologica Lituanica. 2008; 18(3): 169-73.

18. Stonis JR, Diškus A, Vargas S. Discovery of leaf-mining Tischeriidae (Lepidoptera) in Colombia and their distribution in the Neotropics. Zootaxa. 2019; 4638(2): 219-236. doi.org/10.11646/zootaxa.4638.2.3

19. Xu J, Dai X, Liao C, Diškus A, Stonis JR. Discovery of Ulmaceae-feeding Tischeriidae (Lepidoptera, Tischerioidea), Tischeria ulmella sp. nov., and the first report of the Quercus-feeding T. naraensis Sato in China. Zootaxa. 2018; 4399(3): 361-70. https://doi.org/10.11646/ zootaxa.4399.3.6

20. Xu J, Dai X, Liu P, Bai H, Diškus A, Stonis JR. First report on Paratischeria from Asia (Lepidoptera: Tischeriidae). Zootaxa. 2017; 4350(2): 331-44. https://doi: 10.11646/zootaxa.4350.2.8.
Adam Klasiński, Jonas Rimantas Stonis, Andrius Remeikis

PAGAL GENITALINIŲ STRUKTŪRŲ MORFOLOGIJĄ IDENTIFIKUOTA MOKSLUI NAUJA TISCHERIA ZELLER GENTIES RŪŠIS (LEPIDOPTERA, TISCHERIIDAE), APTINKAMA KAUKAZE

Santrauka

Straipsnyje aprašoma mokslui nauja Tischeria caucasica Klasiński \& Stonis rūšis, 2019 m. aptikta Centrineje Gruzijoje. Trumpai aptariami esminiai diagnostiniai požymiai, leidžiantys identifikuoti šeriuotaūsių (Tischeriidae) taksonus. Pagal genitalinių struktūrų (ypač juxta) morfologiją identifikuota nauja rūšis dydžiu ir forma ženkliai skiriasi nuo anksčiau žinomų giminiškų Tischeria ekebladella ir T. ekebladoides morfologinių struktūrų. Straipsnyje pateikiama išsami naujos rūšies suaugèlių patino ir patelių genitalinių struktūrų morfologijos dokumentacija. Nors naujos rūšies mitybos augalas nèra nustatytas, tačiau manoma, kad T. caucasica lervos, kaip ir kitų artimų Tischeria rūšių, yra ąžuolų lapų minuotojai, mitybos ryšiais galbūt susiję su tyrimų vietoveje aptiktais Quercus petraea (Matt.) Liebl., Q. macranthera Fisch. \& C. A. Mey. ex Hohen. arba Q. robur $\mathrm{L}$.

Raktažodžiai: lapų minuotojai, nauja rūšis, šeriuotaūsiai, Tischeria caucasica 